\title{
Investigating the Influence of Absorptive Capacity of Recipients within Cross- Border Transfer of Knowledge: Evidence from Emerging Markets
}

\author{
Authors: Hina Mehreen, Hussain Gulzar Rammal, Vijay Pereira, and Manlio Del Guidice \\ Accepted for publication in International Marketing Review on 20 April 2021 \\ DOI: 10.1108/IMR-11-2020-0264
}

\begin{abstract}
The cross-border transfer of technological and managerial knowledge, including marketing strategies, is often focused on the recipients' absorptive capacity or the country's institutional environment. However, factors such as the recipient's learning intent, the attractiveness of the knowledge source, and the relationship quality between the recipient and the source, and their influence on the effective and efficient transfer of knowledge in emerging markets have remained under-researched. In high-technology sectors, the nature of the intra-organizational knowledge being transferred (especially tacit knowledge) is critical for the organization to achieve a competitive advantage. This study addresses these issues and empirically tests these relationships using data from Pakistan's cellular network sector. A total of 180 completed survey responses from all cellular network providers operating in the country were analyzed. Using multiple regression analysis, we find support for our hypotheses and highlight how the highly educated workforce and the motivation to learn impact the effective cross-border sharing of technological and marketing knowledge.
\end{abstract}

Keywords: Absorptive-Capacity; Cross-Border Transfer of Knowledge; Emerging Markets;

Pakistan; Telecommunication-industry 


\section{INTRODUCTION}

Emerging economies are home to 85 percent of the world's population (Lagarde 2016). They are, by the sheer size of their population, important markets for multinational enterprises (MNEs) (İpek 2020). The International Business (IB) literature has acknowledged the importance of these markets, not just for the opportunity to expand and sell to a large consumer base but also as a potential source for new knowledge and innovation (Govindarajan and Ramamurti 2011). However, while credited for generating new ways of conducting activities such as frugal innovation (Zeschky, Widenmayer and Gassmann 2011), emerging markets are generally seen as lagging behind the developed world in innovation and innovative thinking due to issues with knowledge absorptive capacity (Zhang, Li, Li and Zhou 2010). Absorptive capacity refers to the ability of organizations, and individuals within it, to understand and apply the information they receive (Human 2020). Cuervo-Cazurra and Rui (2017) classify the barriers to absorptive capacity as internal (managerial biases and weak social integration mechanisms) and external (muted activation triggers, conflicting source relationships, and feeble appropriability regimes) to the organization. They identify certain conditions in emerging markets that can heighten these barriers.

For foreign MNEs operating in emerging economies, the barriers to cross-border knowledge transfer and recipients' inability or limited capacity to absorb knowledge can reduce their competitive advantage in the host economy. This is especially the case in high-technology sectors where knowledge plays a critical role in developing new technology and management strategies (including key marketing and operational strategies) by firms to keep pace with the industry's rapid innovation (Martín-de Castro 2015, Mol and Brandl 2018). While there have been some studies on firms' absorptive capacity in emerging economies (see, for example, Khan, Lew and Marinova 2019), most of these have focused on institutional level issues in the knowledge transfer process. In particular, the nature of the transferrable knowledge (tacit knowledge, such as marketing 
strategies), the effectiveness and efficiency of technological knowledge transfer, the recipient's learning intention, the knowledge source's attractiveness, and the quality relationship between the source and recipient organizations are issues that the literature has identified as being critical to the success of inter-and intra-organizational knowledge transfer, and require further exploration (Søberg and Wæhrens 2019, Szulanski, Ringov and Jensen 2016), especially in the context of emerging markets.

The current study investigates the effectiveness and efficiency of cross-border knowledge transfer in Pakistan's cellular network sector. By examining cross-border knowledge transfer in terms of effectiveness (comprehension and usefulness) and efficiency (speed and economy), the study contributes to the literature on knowledge management and global value chains. The recipient's learning intention, knowledge source attractiveness, and the quality of relationships are highlighted as cross-border knowledge transfer antecedents. This study tests these relationships in a knowledge-intensive industry in an emerging market.

The choice of Pakistan's cellular network sector to study the knowledge transfer process was based on several factors. Pakistan is the fifth most populous country globally (US Census 2019) and had the $10^{\text {th }}$ highest mobile-cellular subscription in 2018 (Statista 2019). Four companies provide cellular service in Pakistan, and international firms own them all. Therefore, Pakistan provides an interesting context to study the technological and managerial knowledge transfer, including marketing strategies knowledge flows from the global headquarters, and the continuous collaboration and communication with their foreign knowledge sources (Chao, Samiee and SaiChung Yip 2003).

Foreign knowledge sources transfer the knowledge related to broadband and cellular networking technologies. Pakistani cellular companies, as knowledge recipients, therefore, need to articulate knowledge in a way that the processes and procedures involved in the implementation of 
these technologies and management strategies can be implemented alongside their ongoing projects and processes. Hence, the factors involved in the effective and efficient cross-border knowledge transfer based on both knowledge source and knowledge recipient, in terms of 'recipient organization's intention toward acquiring and learning external knowledge', readily available knowledge from source organizations across borders', and 'the quality of the relationship between source and recipient organizations' are significantly important in the process.

This study finds that the individuals' lack of capacity or institutional concerns are not the barriers to knowledge transfer in emerging market organizations. Instead, the perceived value of the knowledge being transferred and the recipients' motivation to learn the new knowledge determines the effective and efficient transfer of knowledge. By examining the roles of the knowledge source, the recipients, and their relationship in cross-border transfer of knowledge, this study contributes to research and practice.

\section{KNOWLEDGE TRANSFER AND HYPOTHESES DEVELOPMENT}

Knowledge is often described as the most valuable resource (Grant 1996) and the main driver for economic value (Drucker 1999). Therefore, it is critical for the success of organizations to manage and protect this asset. This is especially true for MNEs, who attempt to transfer this resource across borders to maintain their competitive advantage and add to their knowledge through acquisition and lateral transfer between the organization's network partners. To understand the process of knowledge transfer and its complexity, we need to discuss how knowledge is classified. Knowledge can be classified as tacit or explicit. Tacit knowledge refers to knowledge held by individuals in an implicit form. The transfer of this knowledge requires interaction between individuals and to convert it into an explicit form. Nonaka and Takeuchi (1995) proposed the SECI 
model to convert tacit knowledge into an explicit form and identified socialization as a key element of this process. This requires the knowledge source and receiver to work together to learn from each other. Explicit knowledge covers knowledge available in a codified form, including document, reports, and manuals.

\section{Knowledge Transfer Process:}

Easterby-Smith, Lyles and Tsang (2008) describe the cross-border knowledge transfer process as complex due to the diversified nature of processes and procedures involved in the international environment due to the legal frameworks, nature of regulations, cultural and linguistic differences. According to Lopez and Esteves (2013), organizations seek external sources of knowledge to strengthen their existing knowledge base for innovation and sustain their international competitive advantage. External stakeholders and international strategic alliance partners play a vital role in introducing and acquiring new external knowledge by the organization. For MNEs, whose business networks are spread across national boundaries, acquiring knowledge beyond their home country could be linked to new technological innovation, implement a new idea, develop a new innovative product, or upgrade the existing products and processes.

To enhance innovation, organizations focus on developing an effective and efficient knowledge transfer process. Moreover, they need to generate their internal capabilities to effectively and efficiently integrate, absorb, and functionalize new external knowledge (Jensen and Szulanski 2004). The effectiveness of knowledge is measured by looking at the degree to which the transfer goals have been achieved, and efficiency measures the number of resources used to produce a unit of output (Daft 1998). Pérez-Nordtvedt, Kedia, Datta and Rasheed (2008) identified four subdimensions associated with successful knowledge transfer processes across borders. These dimensions include comprehension, usefulness/convenience, speediness, and economy. 


\section{Dimensions of Knowledge Transfer:}

Spraggon and Bodolica (2012) argue that transferred knowledge is only effective if the recipient organization comprehends it. Hence, inter or intra-organizational knowledge transfer should be conducted in a useable and explicable manner (Zahra, Ireland and Hitt 2000). Where the transferred knowledge contains technical information that cannot be easily comprehended, then a third party's involvement to provide relevant training may be required (Paulin and Suneson 2012). This is especially relevant in instances where the transferred knowledge is tacit and intangible.

For the transferred knowledge to be relevant, it has to be seen as useful and important to the recipient organization's requirements (Simonin 2004, Tortoriello, Reagans and McEvily 2012). This particular characteristic of knowledge is most significant for the knowledge-based requirement of the recipient organization. As the increasing expansion of technological and managerial competencies in the global environment are accountable for creating value for the MNEs in a distinctive way (Martin and Salomon 2003).

The speed of knowledge transfer is the rate at which recipient organizations receive knowledge from external sources (Wang and Wang 2012, Zahra et al. 2000). Market conditions vary across countries, which influences organizations' capacity to transfer and absorb knowledge, and this, in turn, affects the speed at which knowledge transfer takes place (McDermott and Corredoira 2010).

The knowledge transfer economy is associated with the cost of the knowledge sharing process between the source and recipient organizations (Casimir, Lee and Loon 2012, Szulanski 1995). Historically, MNEs performed their knowledge transfer processes using their knowledge assets to develop innovative products and services and disseminate them worldwide (Khatri, Baveja, Agrawal and Brown 2010, Rammal and Rose 2014). This process had little or no 
transaction cost (Almeida, Song and Grant 2002). However, in contemporary business practice, the development of new products and processes is more internationalized. To optimize the knowledge transfer procedure economically, organizations are developing their absorptive capacity (Song 2014).

Successful international knowledge transfer of technological and managerial knowledge, such as marketing strategies, requires constant collaboration to facilitate knowledge flow and communication between the source and recipient of knowledge across the national boundaries (Williams and Lee 2011). Park, Vertinsky and Becerra (2015) highlight the importance of socialization and argue that organizations should facilitate social communities where experts can collaborate and innovative products and services by improving their cross-border knowledge transfer activities.

In the telecommunication sector, the transfer of knowledge associated with cellular technology involves sharing explicit knowledge related to the equipment, and tacit knowledge such as management knowledge, including marketing strategies, related to its use to achieve efficiency. Therefore, it is important to understand the nature of the knowledge being shared. Extant literature acknowledges the importance of tacit knowledge in transferring technology and innovation (Cavusgil, Calantone and Zhao 2003). Tacit knowledge such as marketing strategies is considered to be more difficult to transfer due to the knowledge being embedded in the individual. The motivations of the knowledge source and the recipient to share and absorb the knowledge may differ. The socialization process with the interaction between the knowledge source and the recipient is critical in the tacit knowledge transfer (Guo, Jasovska, Rammal and Rose 2020). One avenue pursued by firms to facilitate this form of interaction is sending expatriates to work at foreign subsidiaries (Hocking, Brown and Harzing 2007). However, emerging markets can pose many challenges to the socialization process. Depending on the country's security conditions, firms 
may be unwilling to send expatriates to the country. Hence, the tacit knowledge, such as marketing strategies, needs to be externalized and converted into an explicit form for recipients in the host country to use. Therefore, we posit that:

Hypothesis 1: In emerging economies, effective and efficient cross-border knowledge transfer is positively influenced by the nature of the knowledge.

Learning is an important aspect of intra-organizational knowledge transfer and can prevent loss of information from employee turnover, ensuring that the company maintains its competitive advantage throughout their global operations (Calantone, Cavusgil and Zhao 2002). The transfer of intraorganizational knowledge to emerging economies can pose several challenges. One of the major challenges relates to what information, knowledge, and innovation is the source willing to share. The higher political risk in many emerging economies may also result in fewer firms willing to share the latest technology and innovation (Dang, Jasovska and Rammal 2020). However, as Khan et al. (2019) highlighted, if the recipients in emerging markets are motivated to acquire new knowledge and view it as useful, they will be willing to learn. They may also have a positive view of the foreign source of knowledge. Therefore, we hypothesize that:

Hypothesis 2: The motivation to acquire new tacit knowledge is positively associated with the recipients' learning intent.

Hypothesis 3: The usefulness of the tacit knowledge being transferred positively influences the foreign source's attractiveness.

One of the challenges of operating in emerging economies is the poor institutional environment that organizations have to deal with (Lebedev, Peng, Xie and Stevens 2015), that is, institutional voids (Khan et al., 2019). Organizations apply certain strategies to deal with these 
challenges (Marquis and Raynard 2015), and one of these involves developing individual relations. These relations become the basis for individuals to trust each other and help address stickiness related to knowledge sharing. Hence, we posit that:

Hypothesis 4: The comprehension of cross-border transferred tacit knowledge is positively associated with the relationship quality between the foreign source and the recipient.

As highlighted earlier, in high-the sectors like telecommunication, the effective and speedy transfer of technological and managerial knowledge, including marketing strategies, is critical for the organization's success. Hence, if the recipient's motivation is to learn, the source's attractiveness in terms of the knowledge being transferred, and the nature of the relationship between the source and recipient is positive, then the organization will be able to transfer knowledge effectively and efficiently in emerging markets. Therefore, we hypothesize that: Hypothesis 5: Emerging market recipients' learning intent, source's attractiveness, and relationship quality have a positive influence on effective and efficient cross-border knowledge transfer.

Hypothesis 6: Emerging market recipients' learning intent, source's attractiveness, and relationship quality mediate the relationship between the nature of knowledge and its effective and efficient crossborder transfer.

\section{METHODOLOGY}

\section{Cellular network sector in Pakistan}

The global telecommunications sector has experienced rapid growth and transitioned from fixed telecommunication (home phones) to mobile telecommunications and wireless broadband. This transition has been a critical driver of innovation and will continue to contribute in the future as the Internet of Things (IoT) becomes a reality in business and everyday activities, including 
consumer shopping (Ameen, Tarhini, Reppel and Anand 2021, Ameen, Tarhini, Shah and Madichie 2020) and use of wearable technologies (Ferreira, Fernandes, Rammal and Veiga 2021). The growth is not limited to developed economies, with high-levels of growth witness in emerging economies.

Despite having millions of new subscribers every month, and ranked as one of the fastestgrowing 3G and 4G market, Pakistan's cellular sector faces many market challenges (Hanif, Yunfei, and Hanif, 2018). While the mobile cellular data usage has increased from 574 petabytes in 2016-17 to 1,545 petabytes in 2018-19 and the number of mobile cellular subscribers increasing to 164 million (November 2019 figures), the total amount of investment in the telecommunication sector (both FDI and by operators) has decreased from US\$1088.1 million in 2016-17 to US\$871.8 million (estimate) in 2018-19 (PTA 2019). Internet infrastructure development and expansion remain stagnant, and Pakistan is ranked 102 globally for internet speed (Zaman 2019). One of the challenges the cellular sector of Pakistan faces is that the technical know-how is located in the foreign headquarters. According to the World Bank's Enterprises Survey Data for Pakistan, 22.1\% of firms were used technology licensed from foreign companies, which was much higher than the average for firms in South Asia (11.4\%) and the rest of the world (15\%) (The World Bank 2020). Hence, the four organizations operating in the sector require effective and efficient cross-border knowledge transfer of technological and managerial knowledge, such as marketing strategies, processes to ensure the implementation of new and innovative broadband networking technologies and associated services that the parent companies transfer.

The four organizations that provide cellular network services in Pakistan are Jazz, Telenor Pakistan, Ufone, and Zong. Jazz (formerly known as Mobilink) was founded in 1994 as a joint venture between a Pakistani firm and Motorola. In 2007, Egypt-based Orascom acquired 100 percent shares of the company. In 2010, Russian firm Vimpelcom (now known as VEON and 
headquartered in Amsterdam) became the major shareholder of Mobilink. In 2015, Vimpelcom acquired another Abu-Dhabi owned Pakistani cellular company, Warid, and in 2016 Mobilink was rebranded as Jazz. The company has over 59 million subscribers in Pakistan and employs 3000 people in the country (Jazz 2019). Launched in 2005, Telenor Pakistan is a fully owned subsidiary of the Norwegian Telenor Group. It has a subscriber base of 45 million and employs close to 2000 people in Pakistan (Telenor 2019). Zong is a wholly-owned subsidiary of the Chinese State-owned China Mobile (Zong 2019). Established in 1990 as Paktel (co-established by Cable \& Wireless), the company was the first to be granted a license to offer cellular service in Pakistan. In 2000, the company was acquired by the Luxemburg based Millicom International Cellular SA. China Mobile acquired Paktel in 2008 as its first international investment (Kong, Poon and Dean 2007) and renamed it, Zong. It has a subscriber base of 34 million in Pakistan. Ufone has a subscriber base of 22 million and is a wholly-owned subsidiary of the Pakistan Telecommunication Company Limited (PTCL). Following the privatization of PTCL in 2006, Ufone became part of the UAE-based Etisalat group (Ufone 2019). Table 1 provides an overview of these companies and their market shares.

Table 1: Brief Profile of the Network Operators in Pakistan

\begin{tabular}{llllll}
\hline $\begin{array}{l}\text { Service } \\
\text { Provider }\end{array}$ & $\begin{array}{l}\text { Year of } \\
\text { Establishment }\end{array}$ & Parent Company & $\begin{array}{l}\text { Number of } \\
\text { subscribers } \\
\text { in Pakistan }\end{array}$ & $\begin{array}{l}\text { Market Share } \\
\text { in Pakistan } \\
\mathbf{( 2 0 1 8 - 1 9 )}\end{array}$ & $\begin{array}{l}\text { Head of } \\
\text { Operations in } \\
\text { Pakistan }\end{array}$ \\
\hline Jazz (Mobilink) & 1994 & VEON (Netherlands) & $>59$ million & $36.9 \%$ & Aamir Ibrahim \\
\hline Telenor & 2005 & Telenor (Norway) & 45 million & $27.5 \%$ & $\begin{array}{l}\text { Irfan Wahab } \\
\text { Khan }\end{array}$ \\
\hline Zong & & & & $21.6 \%$ & Liu Dianfeng \\
& 1990 (renamed & China Mobile (China) & 34 million & & Rashid Khan \\
\hline Ufone & Zong in 2008) & & & & $14 \%$ \\
\hline
\end{tabular}

Sources: (Jazz 2019, PTA 2019, Telenor 2019, Ufone 2019, Zong 2019)

Except for Zong, the other service providers have a local CEO. The senior management team of the subsidiaries are also made up of Pakistani nationals. There could be many reasons for 
this. First, Pakistan has been the target of frequent terrorist attacks in the last two decades and is ranked as the $11^{\text {th }}$ most dangerous country in the world to live according to the Institute of Economics \& Peace's (2019) Global Peace Index. The lack of personal safety and security makes it one of the least attractive destinations for expatriates. Second, the use of local managers in senior positions may be a recognition by the headquarters of the tacit knowledge, both technological managerial, such as marketing strategies, the staff in Pakistan possess about the domestic industry, institutional environment, and consumer needs. Hence, our focus is on the technology-and marketing-related strategies and knowledge transferred to the recipient in the explicit form. Since Zong was China Mobile's first international purchase, the presence of the expatriate as head of the operations in Pakistan may suggest a desire to learn from the local staff about operations and marketing in other emerging markets, which was a critical reason for their overseas expansion (Kong et al. 2007). However, this study does not focus on the reverse knowledge transfer process.

In addition to the challenges associated with cross-border knowledge transfer, these organizations face the challenges of government regulations regarding the collection of taxes on the top-up of prepaid credits, occasional disruption of mobile network service by the government under the excuse of security and safety, and high level of duties and taxes on the import of telecommunication equipment (Bhatti 2019, Freedom House 2020, Zaman 2019).

\section{Sample, data collection, and measurement}

To test our hypotheses, we collected data using quantitative survey questionnaires. The survey data were collected from all four organizations from their country headquarters in Islamabad, Pakistan's capital city. Thus, we were able to capture the entire population of cellular network providers in Pakistan. We sought information from the planning and networking managers, team leaders, and team members who are specifically working on the networking and broadband projects 
related to supply 3G and 4G technologies in Pakistan and were based in the Pakistani headquarters. Using a simple random sampling technique was applied, and the survey was distributed among the relevant individuals in the four organizations. We chose the survey technique

The appropriate sample size for the current study was determined by following Green's (1991) rule-of-thumb $(\mathrm{N} \geq 104+\mathrm{m})$, where $\mathrm{m}$ is the number of independent variables and $\mathrm{N}$ is the sample size. Since the study uses one independent variable and three mediators, the sample size needed to be greater than 105. In total, 200 questionnaires were distributed among the four organizations (50 questionnaires in each organization). A total of 180 completed questionnaires were returned, which translates to a 90 percent response rate. The extremely high response rate was achieved by following several steps. First, the researchers contacted the organizations to seek their approval and support for the study. Moreover, they agreed to provide us access to the team leaders of various completed and ongoing projects related to these technologies and their team members in their planning and networking department.

Second, instead of setting up an online survey portal or emailing the survey questionnaires, copies of the survey questionnaires were printed and physically distributed at the organizations' headquarters. Yuliansyah, Rammal and Rose (2016), in their study of Indonesian service firms, highlighted the importance of distributing physical rather than electronic copies for a higher response rate in emerging economies. Finally, appointments were made with the managers of the organizations to visit them again after 10 days to collect the completed questionnaires. Table 2 summarizes the educational qualification of the respondents who completed the questionnaires. The results suggest a highly educated workforce in Pakistan's cellular technology sector and provide insights into the recipients' absorptive capacity. This has implications for the efficient transfer of knowledge through the implementations of formal systems. 
Table 2: Educational Background of the Respondents

\begin{tabular}{l|c|c|c}
\hline Educational Qualification of Respondents & Frequency & Percent & $\begin{array}{c}\text { Cumulative } \\
\text { Percent }\end{array}$ \\
\hline Graduate & 99 & 55 & $\mathbf{5 5}$ \\
\hline Masters or Above & 81 & 45 & $\mathbf{1 0 0}$ \\
\hline Total & $\mathbf{1 8 0}$ & $\mathbf{1 0 0}$ & \\
\hline
\end{tabular}

Table 3 highlights the professional experience of the respondents. Nearly three-quarters of the respondents had less than 5 years of experience in the sector. Only 39 percent of the employees have job experience of more than 5 years, out of which only 11 percent of employees have experience of more than 10 years. The cellular industry has been actively promoted in Pakistan and has experienced rapid growth in the last decade. The lower-level of experience of the respondents in the sector reflects this infancy of the sector.

Table 3: Professional Experience of the Respondents

\begin{tabular}{l|c|c|c}
\hline \multicolumn{1}{c|}{ Job Experience } & Frequency & Percent & $\begin{array}{c}\text { Cumulative } \\
\text { Percent }\end{array}$ \\
\hline less than 1 year & 62 & 34 & $\mathbf{3 4}$ \\
\hline 1-5 years & 67 & 37 & $\mathbf{7 1}$ \\
\hline 5-10 years & 32 & 18 & $\mathbf{8 2}$ \\
\hline over 10 years & 19 & 11 & $\mathbf{1 0 0}$ \\
\hline Total & $\mathbf{1 8 0}$ & $\mathbf{1 0 0}$ & \\
\hline
\end{tabular}

The questionnaire used in the survey was adapted from Pérez-Nordtvedt et al.’s (2008) study, which investigated the effectiveness and efficiency of cross-border knowledge transfer. Knowledge is the independent variable related to the transfer of $2 \mathrm{G}, 3 \mathrm{G}$ and $4 \mathrm{G}$ radio access equipment supply and related services. The score of learning intention of knowledge recipient, the attractiveness of knowledge source, and their relationship quality are treated as mediating variables. The effective and efficient knowledge transfer across borders is the dependent variable in this study. All variables in this study are measured using a 5-points Likert scale that ranged from $1=$ strongly disagree to $5=$ strongly agree. The degree of association between different variables is 
measured through correlation analysis. Furthermore, Cronbach's alpha test is used to measure the internal reliability of the variables. Since mediators are involved in the research model, Ordinary Least Square Model and Hayes' (2012) PROCESS was undertaken using SPSS software to analyze collected data.

We use factor analysis and other reliability analysis tools to test the psychometric properties of the measures. Exploratory Factor analysis (EFA) is used to identify and confirm the survey items' underlying structure (Bratt et al., 2012). Appendix Tables A1-6 provide the detailed results of the psychometric properties of our measures and other tests. Principal component analysis is used along with Varimax Rotation to extract rotations, and an eigenvalue greater than 1 is used to determine the survey questions. Based on acceptability criteria, factors with a value greater than 0.4 were accepted (Kontoleon, 2003) and added to the questionnaire. The extracted variables are labelled:

- Nature of Knowledge (Tacit Knowledge)

- Recipient Learning Intent

- Source Attractiveness

- Relationship Quality

- Effective and Efficient Cross-border Knowledge Transfer

The Kaiser-Meyer-Olkin measure of sampling adequacy is 0.875 , which shows the data is appropriate for the exploratory factor analysis. Bartlett's test of sphericity with the significance value 0.000 shows that the correlation matrix for the questions of tacit knowledge, recipient learning intent, source attractiveness, relationship quality and effective and efficient cross-border knowledge transfer is not an identity matrix. Both tests indicate the data's fit for EFA.

The cumulative variance was used to check the appropriateness of the data. A greater than $60 \%$ variance is considered reliable, and data with variance below is considered insignificant for 
exploratory factor analysis (Brett, 2012). 56.263 of the variance is accounted for tacit knowledge, recipient learning intent, source attractiveness, relationship quality and effective and efficient cross-border knowledge transfer, which is within the acceptable range so the EFA could be run. Finally, regression analysis was undertaken on these variables. The regression analysis results show that these five variables extracted from the EFA are significant (see Tables A5, A6, and A7).

\section{DATA ANALYSES AND RESULTS}

Minimum, maximum, means, standard deviations, correlations and psychometric properties associated with the study variables are presented in Table 4. In the analysis, the maximum is used to identify a possible outlier or a data-entry error. One of the simplest ways to assess the spread of data is to compare the minimum and maximum values. Suppose the maximum value is very high, even when considering the center, the spread, and the data's shape. In that case, it should prompt an investigation into the possible cause(s) for the extreme value. Similarly, the minimum value also used to identify a possible outlier or a data-entry error. In this study, the minimum and maximum values show that the data is spread widely without any outliers being identified.

The values of the Pearson Correlation depict the relationship between the variables used in this study. The values of correlation among variables range between -1 and +1 . If the value of correlation is zero, it depicts no correlation between the respective variables. The value close to -1 depicts that there is a negative correlation among the variables. Whereas the values range between 0 and +1 indicate the positive correlation between the respective variables. Correlation values of less than 0.3 indicate a positive correlation between the variables and depict that both variables are proceeding in the same direction. But in this case, there is a weak correlation between variables. If the value of correlation lies between 0.3 and 0.6 , it indicates a moderate correlation between the variables. However, a value of more than 0.6 suggests a strong correlation between the two respective variables. All values of correlation lie between 0.3 and 0.6 , indicating that the variables 
are moderately correlated. Cronbach Alpha test has been applied to check the scales' reliability and the data to confirm reliability. The threshold value of alpha must be greater than 0.7 (Bland and Altman, 1997), which is the case in this research, confirming that the variables' scales are reliable.

Table 4: Psychometric Properties, Means, standard deviations and correlations of Variables

\begin{tabular}{|c|c|c|c|c|c|c|c|c|c|}
\hline & Items & $\begin{array}{c}\text { Cronbach } \\
\text { Alpha }\end{array}$ & Min & $\operatorname{Max}$ & Mean & Std. dev. & 1 & 2 & 3 \\
\hline 1.Tacit Knowledge & 7 & 0.825 & 1.17 & 4.83 & 3.6213 & 0.7606 & 1 & & \\
\hline 2. Recipient Learning Intent & 7 & 0.870 & 1.14 & 5.00 & 3.1149 & 0.7370 & $.571 * *$ & 1 & \\
\hline 3. Source Attractiveness & 5 & 0.851 & 1.00 & 4.44 & 3.1040 & 0.7092 & $.458 * *$ & $.361 * *$ & 1 \\
\hline 4. Relationship Quality & 5 & 0.914 & 1.17 & 4.83 & 3.5139 & 0.7606 & $.574 * *$ & $.354 * *$ & $.297 * *$ \\
\hline $\begin{array}{l}\text { 5.Effectiveness and } \\
\text { Efficiency in Cross-Border } \\
\text { Knowledge Transfer }\end{array}$ & 5 & 0.902 & 1.44 & 5.00 & 3.4575 & 0.6018 & $.428 * *$ & $.301 * *$ & $.324 * *$ \\
\hline
\end{tabular}

Ordinary least squares (OLS) regression was used to test the hypotheses and investigate the factors influencing the effective and efficient cross-border knowledge transfer from source to recipient. The relationship between the dependent and independent variables is analyzed using linear regression analysis. The same method is followed to analyze the relationships between the independent variable and each mediator and their effects on the dependent variables. However, the independent variable's overall effect on the dependent variable with the mediation effect of all three mediators is tested through Hayes' PROCESS mediation test. The regression analysis is performed by creating dummy variables for demographic variables, including the name of the company, job position, education and experience of the respondents and used as controlled variables. Table 5 summarizes the analysis of these relationships between variables.

Model-1 confirms that the nature of knowledge positively influences effective and efficient cross-border knowledge transfer. R2 denotes the fit of the data to the model and the coefficient of 
the model. The value of R2 is 0.1834 , which suggests that the independent variable has an $18 \%$ impact on the dependent variable (effective and efficient cross-border knowledge transfer). The Ftest is performed to check the overall significance of the regression model. The model is considered significant if it is below the margin of error of 0.05 . The value of significance is 0.0000 , indicating that the independent variable is significant as the value of $\mathrm{p}$-value $(0.000<0.05)$ and the value of $\mathrm{F}$ $(1,178)(\mathrm{p}<.001)=39.9854$, thereby shows support for H1. The significance value for the dependent and independent variables can be seen as it is less than 0.050 . Model- 1 indicates that the nature of knowledge Beta Coefficient is significant at p-value 0.000, the value of Beta coefficient is 0.3389. This shows that if we bring a one-unit change in tacit knowledge, the effective and efficient cross-border knowledge transfer will be affected by 0.3389 unit. Besides, output also provides the bootstrapped confidence interval and the value of zero is checked whether it exists within the interval range or not (99 and 95\% confidence). As LLCI shows the lower level confidence interval and ULCI is showing upper-level confidence interval. The existence of zero within the interval range depicts that the indirect effect is insignificant. In Table 8, the true indirect effect is $95 \%$ likely to range from $0.2331-0.4446$. The estimated effect is 0.3389 lying in between these two values and showing a significant indirect effect

Concerning $\mathrm{H} 2$, whether the motivation to acquire tacit knowledge (independent variable) positively influences the recipient learning intent (mediating variable), Model-2 in table 5 shows that the value of R2 is 0.0904 and its significant p-value 0.000 is less than 0.05 and supports $\mathrm{H} 2$. Model-3 shows the relationship between the perceived usefulness of the tacit knowledge being transferred and the foreign source's attractiveness (H3). The value of R2 is 0.1048 , which suggests that the value of the tacit knowledge has a $10.48 \%$ impact on the source attractiveness. The independent variable is significant, as shown by the p-value 0.000 , and $\mathrm{H} 3$ is supported. Hypothesis 4 focused on comprehending the cross-border transfer of tacit knowledge and the relationship 
quality between the foreign source and the recipient. Model- 4 summarizes the regression model, where the $\mathrm{R} 2$ value is 0.0600 , which suggests that tacit knowledge has a $6 \%$ impact on the relationship quality. The p-value also shows that the variables are significant, and the model provides support for hypothesis 4 .

The significance value for recipient learning intent, source's attractiveness and relationship quality, and effective and efficient cross-border knowledge transfer (H5) is less than 0.050 (see Model-5 in table 5). The table indicates that if a one-unit change was made in the recipient learning intent, source's attractiveness and relationship quality, the effective and efficient cross-border knowledge transfer would be affected by $0.327,0.206$ and 0.4082 units, respectively. The indirect effect is significant as the values of upper and lower level confidence interval lie between the range without any value equal to zero. Hayes (2012) PROCESS analysis was applied to check the mediation effect of recipient learning intent, source attractiveness and relationship quality between the relationship of nature of knowledge (tacit knowledge) and effective and efficient cross border knowledge transfer (H6). The Beta Coefficient indirect effect of the dependent variable on the independent variable in the presence of mediating variables is significant at the value of 0.0009 , and Beta coefficient is 0.1471 . Hence, we find support for the hypothesis (H6) that the nature of knowledge (tacit knowledge) positively influences the effective and efficient cross-border knowledge transfer with the mediating effect of recipient learning intent, the source's knowledge attractiveness, and relationship quality. 
Table 5: Analysis of relationship among variables

\begin{tabular}{|c|c|c|c|c|c|c|}
\hline Variables & $\mathbf{E E}^{1}$ & $\mathbf{R L I}^{2}$ & $\mathbf{S A}^{3}$ & $\mathbf{R} \mathbf{Q}^{4}$ & RLI,SA,RQ & EE,RLI,SA,RQ \\
\hline $\mathbf{T K}^{5}$ & Model 1 & Model 2 & Model 3 & Model 4 & Model 5 & Model 6 \\
\hline Effect & & & & & & 0.1471 \\
\hline SA & & & & & 0.2060 & 0.0886 \\
\hline $\mathrm{RQ}$ & & & & & 0.4082 & 0.0561 \\
\hline $\mathrm{R}$ & 0.4283 & 0.3006 & 0.3237 & 0.245 & 0.7430 & \\
\hline df1 & 1.0000 & 1.0000 & 1.0000 & 1.0000 & 4.0000 & \\
\hline $\mathrm{df} 2$ & 178.0000 & 178.0000 & 178.0000 & 178.0000 & 175.0000 & \\
\hline $\mathrm{P}$ & 0.0000 & 0.0000 & 0.0000 & 0.0000 & 0.0000 & 0.0009 \\
\hline
\end{tabular}

${ }^{1}$ Effective and efficient cross-border knowledge transfer

${ }^{2}$ Recipient learning intent

${ }^{3}$ Source's attractiveness

${ }^{4}$ Relationship quality

${ }^{5}$ Tacit knowledge 


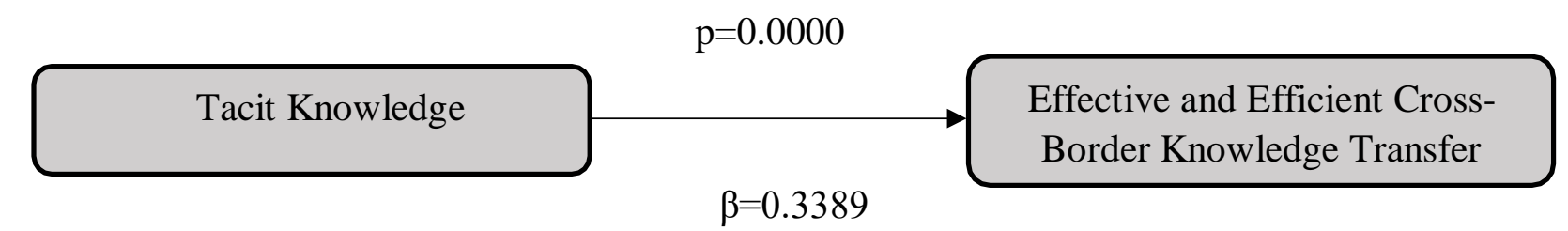

Model 1: Total Effect of Independent Variable on Dependent Variable

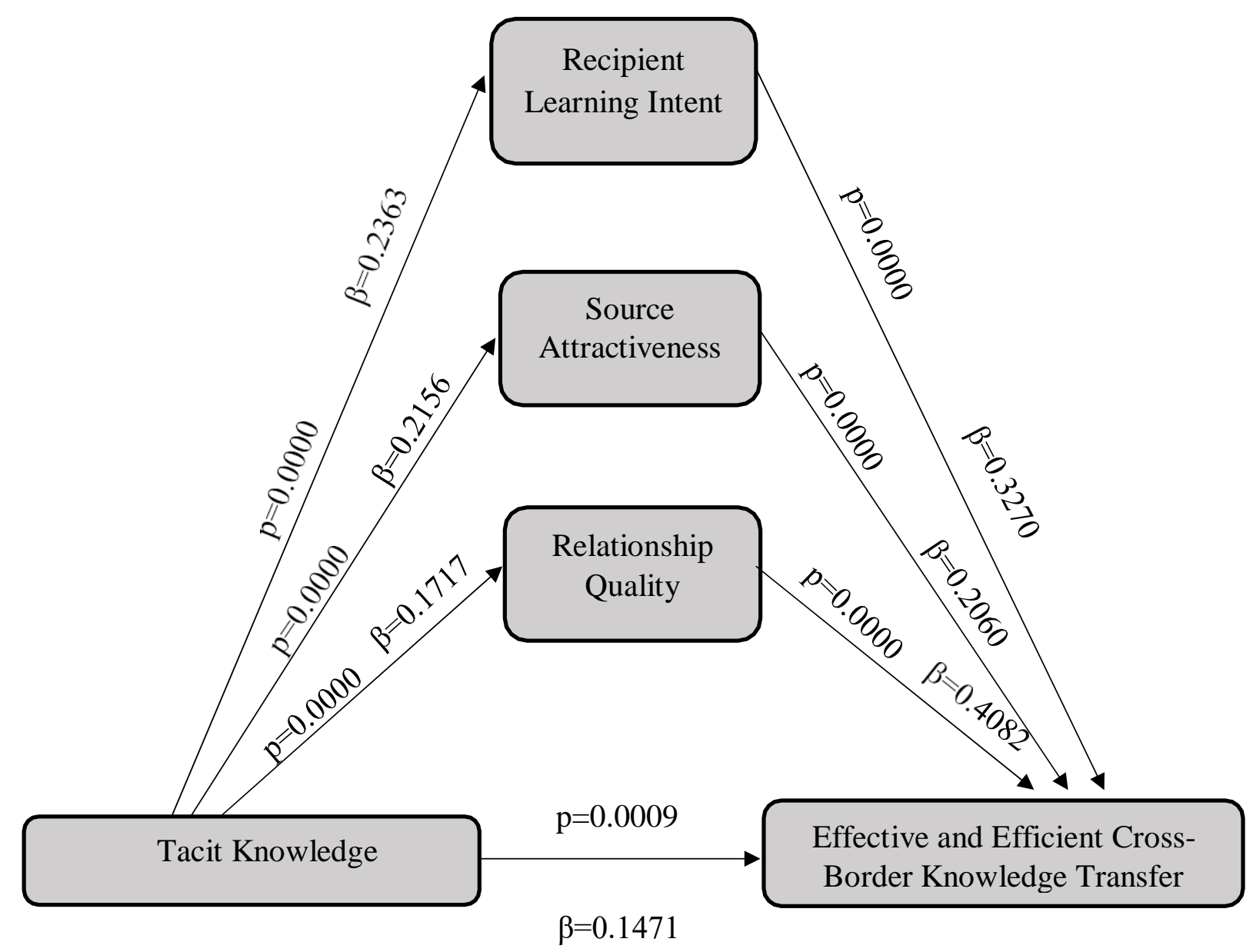

Model 2: Direct and Indirect Effect of Independent Variable on Dependent Variable

Figure 1: Total, Direct and Indirect Effect of Dependent Variable on Independent Variable 


\section{DISCUSSIONS AND CONCLUSION}

This study's findings, with emphasis on mediation analysis, are summarized in Figure 1, where Models 1 and 6 are shown. Model-1 shows the total effect of the independent variable on the dependent variable is $33.89 \%$, in which no mediator has affected the relationship between them, and the relationship is significant at $\mathrm{p}=0.0000$. However, in Model- 6 , the mediating variables' effect has been added to the independent variable's effect on the dependent variable. Therefore, the independent variable's direct effect on the dependent variable in the presence of mediators is $14.71 \%$ and the relationship is significant at $\mathrm{p}=0.0009$. The Hayes and Preacher (2012) model is used for testing the mediating role of Recipient learning intent, source attractiveness and relationship quality. Hayes and Preacher (2012) mediation was applied to analyze the mediation effects. The effect of tacit knowledge on recipient learning intent is $23.63 \%$ and the relationship is significant at $\mathrm{p}=0.0000$. While the effect of recipient learning intent on effective and efficient cross-border knowledge transfer is $32.7 \%$, the relationship is significant at $p=0.0000$. Thus, the mediating effect of recipient learning intent on the relationship between independent and dependent variable is $(0.2363 \times 0.3270=0.091) 9.76 \%$. The effect of tacit knowledge on source attractiveness is $21.56 \%$, and the relationship is significant at $\mathrm{p}=0.0000$. While the effect of source attractiveness on effective and efficient cross-border knowledge transfer is $20.6 \%$ and the relationship is significant at $\mathrm{p}=0.0000$. Thus, the mediating effect of source attractiveness on the relationship between independent and dependent variable is $(0.2156 \times 0.2060=0.0561) 5.61 \%$. The effect of tacit knowledge on relationship quality is $17.17 \%$ and the relationship is significant at $\mathrm{p}=0.0000$. While the effect of relationship quality on effective and efficient cross- border knowledge transfer is $40.82 \%$ and the relationship is significant at $\mathrm{p}=0.0000$. Thus, the mediating effect of relationship quality on the relationship of independent and dependent variable is $(0.1717 \times 0.4082=0.0886)$ $8.86 \%$. Therefore, the indirect effect of recipient learning intent, source attractiveness, and 
relationship quality is $24.24 \%$ on dependent and independent variables.

The findings of the study provide insights and address misconceptions about knowledge sharing and transfer in emerging markets. This study replicates cross-border knowledge sharing's effectiveness and efficiency but in an emerging economy and a high-tech industry (Song 2014). The study's findings show that lack of capacity of the individuals or the institutional concerns are not the barriers that organizations face in transferring knowledge. Instead, it is the perceived value of the knowledge being transferred and the recipient's motivation to learn the new knowledge that determines the effective and efficient transfer of knowledge.

Due to the higher levels of political risk in some emerging market economies, managers may be unwilling to accept expatriate assignments in those countries. Pakistan is one such country that has struggled with terrorism and political violence, and that has minimized the opportunities to achieve tacit knowledge transfer by socialization. Also, the country ranks low in the Human Development Index (154 out of 189 countries) with 8 as the expected the expected number of years of schooling (United Nations Development Programme 2021). Despite these limitations, we find that the cross-border knowledge transfer process in managed successfully in the telecommunications sector.

As Khan et al. (2019) found in the Pakistani automotive sector study, the absorptive capacity of the individuals and the firms remains high. It is, however, dependent on the organization as to whether they are willing to share the latest state of the art technology and management strategies, including marketing strategies, or whether they are sharing old technology and management strategies. The recipient's motivation to absorb and learn new knowledge will depend on whether they perceive the knowledge to be valuable. However, the unique nature of these emerging markets cannot be ignored. For example, organizations will be less likely to share knowledge if the emerging market host economies' institutional environment is still in its infancy 
and property rights cannot be protected or guaranteed. This, in turn, can be a source of mistrust between the source and the recipient.

By developing a strong relationship between the knowledge source and recipient, organizations can attempt to improve the organization's knowledge sharing process. In terms of Pakistan's cellular sector, one can observe a highly educated workforce, which helps facilitate knowledge sharing and provides opportunities for the foreign parent companies to invest further in the market to develop indigenous technology and encourage innovative thinking. This finding is consistent with previous studies that suggest that training and a higher level of education improve individuals' absorptive capacity in technology-related industries (van der Heiden, Pohl, Bin Mansor and van Genderen 2015). However, the institutional environment remains a challenge for both domestic and foreign investors, which is confirmed by the presence of only four organizations in the market, and none of which are Pakistani-owned.

\section{Practical Implications}

The telecommunications sector has become an important vehicle that supports many business activities and innovation (Shearmur, Doloreux and Laperrière 2015). For example, money transfers between consumers using services provided by cellular providers is a popular option used in many emerging economies in Asia and Africa. With cellular connectivity on the rise in rural areas, the market base is set to further expand (Rammal 2019). This provides opportunities for firms to extend their services by offering other consumer products and services, and increased use of wearables technologies (Ferreira et al. 2021). The findings of this study show that the absorptive capacity of individuals in emerging markets is high and latest knowledge about innovative products can be translated and applied in these markets. For firms, this means that the lead learning time in emerging markets may be much less than previously expected, and new products can be introduced 
much faster in these economies.

\section{Limitations and Future research}

In this study, we test whether knowledge can be transferred effectively and efficiently to emerging economies. While there are opportunity to generalize the findings of this study, it has limitation with the focus on one industry in one country. Future studies could break the source of knowledge and test the transfer process separately for explicit and tacit knowledge. Other researchers may also wish to test the findings of this study across regional grouping to investigate whether regional membership influences the level of technology used in the economy and the absorptive capacity of individuals or whether these factors remain unique to each country. 


\section{APPENDICES}

Table A1: KMO and Bartlett's Test

\begin{tabular}{|c|c|c|}
\hline \multicolumn{3}{|l|}{ KMO and Bartlett's Test } \\
\hline \multicolumn{2}{|c|}{$\begin{array}{l}\text { Kaiser-Meyer-Olkin } \text { Measure } \\
\text { Sampling Adequacy. }\end{array}$} & .875 \\
\hline \multirow{3}{*}{$\begin{array}{l}\text { Bartlett's } \\
\text { Sphericity }\end{array}$} & Approx. Chi-Square & 2171.915 \\
\hline & Df & 406 \\
\hline & Sig. & .000 \\
\hline
\end{tabular}

Table A2: Total Variance

\begin{tabular}{|c|c|c|c|c|c|c|}
\hline \multirow{2}{*}{$\begin{array}{l}\text { Compone } \\
\text { nt }\end{array}$} & \multicolumn{3}{|c|}{ Initial Eigenvalues } & \multicolumn{3}{|c|}{$\begin{array}{l}\text { Rotation } \\
\text { Loadings }\end{array}$} \\
\hline & Total & $\begin{array}{l}\% \text { of } \\
\text { Varian } \\
\text { ce }\end{array}$ & $\begin{array}{l}\text { Cumulative } \\
\%\end{array}$ & Total & $\begin{array}{l}\% \text { of } \\
\text { Varianc } \\
\mathrm{e}\end{array}$ & $\begin{array}{l}\text { Cumulativ } \\
\text { e \% }\end{array}$ \\
\hline 1 & 8.230 & 28.380 & 28.380 & 3.677 & 12.680 & 12.680 \\
\hline 2 & 2.736 & 9.435 & 37.815 & 3.578 & 12.338 & 25.019 \\
\hline 3 & 2.175 & 7.501 & 45.316 & 3.228 & 11.129 & 36.148 \\
\hline 4 & 2.016 & 6.951 & 52.267 & 3.028 & 10.442 & 46.590 \\
\hline 5 & 1.159 & 3.996 & 56.263 & 2.805 & 9.673 & 56.263 \\
\hline 6 & 1.048 & 3.613 & 59.876 & & & \\
\hline 7 & .988 & 3.405 & 63.282 & & & \\
\hline 8 & .862 & 2.971 & 66.253 & & & \\
\hline 9 & .798 & 2.751 & 69.004 & & & \\
\hline 10 & .773 & 2.667 & 71.670 & & & \\
\hline 11 & .734 & 2.532 & 74.203 & & & \\
\hline 12 & .675 & 2.327 & 76.529 & & & \\
\hline 13 & .618 & 2.130 & 78.660 & & & \\
\hline 14 & .576 & 1.985 & 80.645 & & & \\
\hline 15 & .541 & 1.865 & 82.510 & & & \\
\hline 16 & .489 & 1.686 & 84.197 & & & \\
\hline 17 & .476 & 1.643 & 85.840 & & & \\
\hline 18 & .465 & 1.605 & 87.445 & & & \\
\hline 19 & .448 & 1.544 & 88.989 & & & \\
\hline 20 & .441 & 1.519 & 90.508 & & & \\
\hline 21 & .412 & 1.421 & 91.929 & & & \\
\hline 22 & .354 & 1.219 & 93.148 & & & \\
\hline 23 & .341 & 1.176 & 94.325 & & & \\
\hline 24 & .334 & 1.152 & 95.477 & & & \\
\hline 25 & .317 & 1.095 & 96.572 & & & \\
\hline 26 & .282 & .972 & 97.543 & & & \\
\hline
\end{tabular}




\begin{tabular}{l|l|l|l|l|l|l}
\hline $\mathbf{2 7}$ & .268 & .924 & 98.467 & & & \\
\hline $\mathbf{2 8}$ & .227 & .783 & 99.250 & & & \\
\hline $\mathbf{2 9}$ & $\mathbf{. 2 1 7}$ & $\mathbf{. 7 5 0}$ & $\mathbf{1 0 0 . 0 0 0}$ & & & \\
\hline
\end{tabular}

Table A3: Rotated Component Matrix

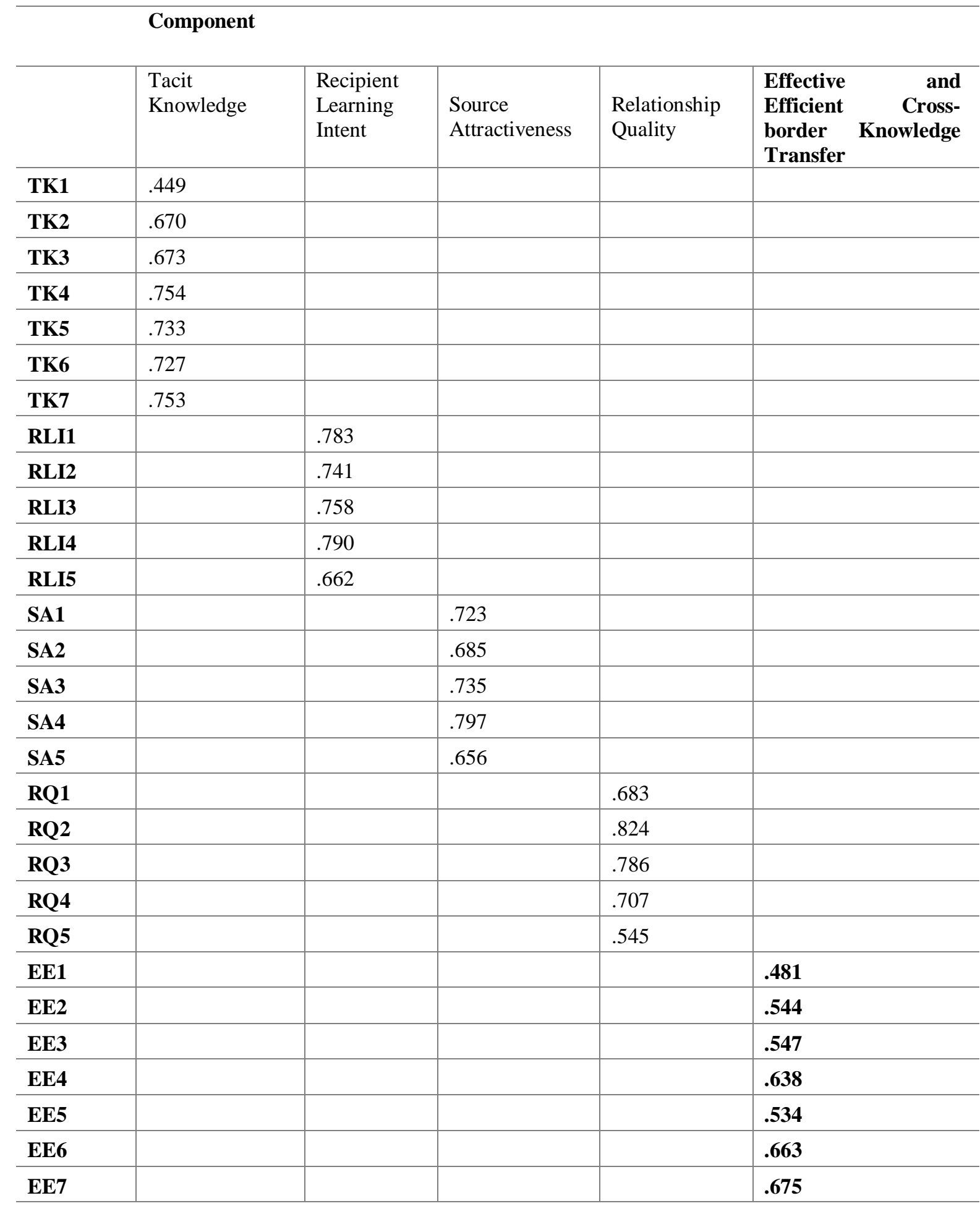

Extraction Method: Principal Component Analysis.

Rotation Method: Varimax with Kaiser Normalization. 
Table A4: Model Summary

\begin{tabular}{c|c|c|c|c|c}
\hline $\begin{array}{c}\text { Mod } \\
\text { el }\end{array}$ & $\mathbf{R}$ & $\begin{array}{c}\mathbf{R} \\
\text { Square }\end{array}$ & $\begin{array}{c}\text { Adjusted } \\
\text { R Square }\end{array}$ & $\begin{array}{c}\text { Std. Error } \\
\text { of the } \\
\text { Estimate }\end{array}$ & $\begin{array}{c}\text { Durbin- } \\
\text { Watson }\end{array}$ \\
\hline 1 & $\mathbf{0 . 9 6 4}$ & $\mathbf{0 . 9 2 9}$ & $\mathbf{0 . 9 2 7}$ & 1.136 & 1.892 \\
\hline
\end{tabular}

a. Predictors: (Constant), REGR factor score 5 for analysis 1, REGR factor score 4 for analysis 1, REGR factor score 3 for analysis 1, REGR factor score 2 for analysis 1, REGR factor score 1 for analysis 1

b. Dependent Variable: Effective and efficient cross-border knowledge transfer

Table A5: ANOVA ${ }^{a}$

\begin{tabular}{|c|c|c|c|c|c|}
\hline Model & $\begin{array}{l}\text { Sum of } \\
\text { Squares }\end{array}$ & df & $\begin{array}{l}\text { Mean } \\
\text { Square }\end{array}$ & $\mathbf{F}$ & Sig. \\
\hline Regression & 2951.774 & 5 & 590.355 & 457.462 & $0.000^{b}$ \\
\hline Residual & 224.547 & 174 & 1.291 & & \\
\hline Total & 3176.321 & 179 & & & \\
\hline
\end{tabular}

a. Dependent Variable: Effective and efficient cross-border knowledge transfer

b. Predictors: (Constant), REGR factor score 5 for analysis 1, REGR factor score 4 for analysis 1, REGR factor score 3 for analysis 1, REGR factor score 2 for analysis 1, REGR factor score 1 for analysis 1

Table A6: Coefficients ${ }^{\mathrm{a}}$

\begin{tabular}{|c|c|c|c|c|c|}
\hline \multirow{2}{*}{ Model } & \multicolumn{2}{|c|}{$\begin{array}{l}\text { Unstandardized } \\
\text { Coefficients }\end{array}$} & \multirow{2}{*}{$\begin{array}{c}\begin{array}{c}\text { Standardiz } \\
\text { ed } \\
\text { Coefficient } \\
\text { s }\end{array} \\
\text { Beta }\end{array}$} & \multirow{2}{*}{$\mathbf{t}$} & \multirow{2}{*}{ Sig. } \\
\hline & B & $\begin{array}{l}\text { Std. } \\
\text { Error }\end{array}$ & & & \\
\hline (Constant) & 24.203 & .085 & & $\begin{array}{c}285.83 \\
7\end{array}$ & 0.000 \\
\hline $\begin{array}{l}\text { Reg. factor score for } \\
\text { variable } 1\end{array}$ & 0.912 & .085 & 0.217 & 10.747 & 0.000 \\
\hline $\begin{array}{l}\text { Reg. factor score for } \\
\text { variable } 2\end{array}$ & 1.569 & .085 & 0.372 & 18.477 & 0.000 \\
\hline $\begin{array}{l}\text { Reg. factor score for } \\
\text { variable } 3\end{array}$ & 1.484 & .085 & 0.352 & 17.477 & 0.000 \\
\hline $\begin{array}{l}\text { Reg. factor score for } \\
\text { variable } 4\end{array}$ & 0.937 & .085 & 0.222 & 11.033 & 0.000 \\
\hline
\end{tabular}




\begin{tabular}{ll|l|l|l|l|l}
\hline $\begin{array}{l}\text { Reg. factor } \\
\text { variable 5 }\end{array}$ & score for & 3.181 & .085 & 0.755 & 37.460 & 0.000 \\
\hline
\end{tabular}

a. Dependent Variable: Effective and efficient cross-border knowledge transfer

APPENDIX B: Revenues Fluctuation in Cellular Sector of Pakistan (PTA, 2016; Atta, 2016)

\section{Cellular}

Revenues

- Mobile phone users in Pakistan

- Telecom subscriptions in June 2015 were 114.7 million

- Telecom subscriptions in 2018 were 153.99 million

- Cellular revenues, however, remained as following

- July 2014 to June 2015: Rs. 317 billion

○ July 2015 to June 2016: Rs. 348.8 billion

- If one factors in the US dollar value (since all telecom operators transact in dollars), national inflation, rupee depreciation and other corresponding factors, then this growth is actually negative.

\section{Data}

Revenues:

- Data Users almost doubled in last one year

- 3G, 4G users on June 2015: 14 million

- 3G, 4G Users on June 2016: 29.3 million

- Data Usage grew $350 \%$ during last one year

- 3G, 4G bandwidth usage in June 2015: 12,443 terabytes per month

- 3G, 4G bandwidth usage in June 2016: 39,821 terabytes per month

- Data Revenues, however, grew only $26 \%$

- Data Revenue in 2014-15: Rs. 77.94 billion

- Data Revenue in 2015-16: Rs. 98.82 billion

Average Revenue Per MB Usage declined 54\% during just one year
o 2014-15: $\$ 0.55$ per MB
o 2015-16: 


\section{References}

Almeida, P., Song, J. and Grant, R.M. (2002), "Are firms superior to alliances and markets? An empirical test of cross-border knowledge building", Organization Science, Vol. 13 No. 2, pp. 147-61.

Ameen, N., Tarhini, A., Reppel, A. and Anand, A. (2021), "Customer experiences in the age of artificial intelligence", Computers in Human Behavior, Vol. 114, pp. 106548.

Ameen, N., Tarhini, A., Shah, M. and Madichie, N.O. (2020), "Going with the flow: smart shopping malls and omnichannel retailing", Journal of Services Marketing, Vol. ahead-ofprint.

Bhatti, H. (2019), "Supreme Court restores all taxes on mobile phone top-ups, wraps up suo motu case", Dawn, Vol. 24 April.

Calantone, R.J., Cavusgil, S.T. and Zhao, Y. (2002), "Learning orientation, firm innovation capability, and firm performance", Industrial Marketing Management, Vol. 31 No. 6, pp. 51524.

Casimir, G., Lee, K. and Loon, M. (2012), "Knowledge sharing: influences of trust, commitment and cost", Journal of Knowledge Management, Vol. 16 No. 5, pp. 740-53.

Cavusgil, S.T., Calantone, R.J. and Zhao, Y. (2003), "Tacit knowledge transfer and firm innovation capability", Journal of Business \& Industrial Marketing, Vol. 18 No. 1, pp. 6-21.

Chao, P., Samiee, S. and Sai-Chung Yip, L. (2003), "International marketing and the AsiaPacific Region: Developments, opportunities, and research issues", International Marketing Review, Vol. 20 No. 5, pp. 480-92.

Cuervo-Cazurra, A. and Rui, H. (2017), "Barriers to absorptive capacity in emerging market firms", Journal of World Business, Vol. 52 No. 6, pp. 727-42.

Daft, R.L. (1998), Organization Theory and Design, South-Western College Publishing, Cincinnati, $\mathrm{OH}$.

Dang, Q.T., Jasovska, P. and Rammal, H.G. (2020), "International business-government relations: The risk management strategies of MNEs in emerging economies", Journal of World Business, Vol. 55 No. 1, pp. 101042.

Drucker, P.F. (1999), "Knowledge-Worker Productivity: The Biggest Challenge", California Management Review, Vol. 41 No. 2, pp. 79-94.

Easterby-Smith, M., Lyles, M.A. and Tsang, E.W. (2008), "Inter-organizational knowledge transfer: Current themes and future prospects", Journal of Management Studies, Vol. 45 No. 4, pp. 677-90.

Ferreira, J.J., Fernandes, C.I., Rammal, H.G. and Veiga, P.M. (2021), "Wearable technology and consumer interaction: A systematic review and research agenda", Computers in Human Behavior, Vol. 118, pp. 106710.

Freedom House. (2020), "Freedom on the Net 2019 - Pakistan", available at: https://freedomhouse.org/country/pakistan/freedom-net/2019 (accessed 10 January 2020).

Govindarajan, V. and Ramamurti, R. (2011), "Reverse innovation, emerging markets, and global strategy", Global Strategy Journal, Vol. 1 No. 3-4, pp. 191-205.

Grant, R.M. (1996), "Towards a knowledge-based theory of the firm", Strategic Management Journal, Vol. 17, pp. 109-22. 
Green, S.B. (1991), "How many subjects does it take to do a regression analysis?", Multivariate Behavioral Research, Vol. 26 No. 3, pp. 499-510.

Guo, Y., Jasovska, P., Rammal, H.G. and Rose, E.L. (2020), "Global mobility of professionals and the transfer of tacit knowledge in multinational service firms", Journal of Knowledge Management, Vol. 24 No. 3, pp. 553-67.

Hocking, J.B., Brown, M. and Harzing, A.W. (2007), "Balancing global and local strategic contexts: Expatriate knowledge transfer, applications, and learning within a transnational organization", Human Resource Management, Vol. 46 No. 4, pp. 513-33.

Human, G. (2020), "Linking absorptive capacity, knowledge transfer and transactive memory", Journal of Business \& Industrial Marketing, Vol. ahead-of-print.

Institute for Economics \& Peace. (2019), "Global Peace Index 2019: Measuring Peace in a Complex World", available at: http://visionofhumanity.org/reports (accessed 8 October 2019). İpek, İ. (2020), "The relevance of international marketing strategy to emerging-market exporting firms: from a systematic review towards a conceptual framework", International Marketing Review, Vol. ahead-of-print No. https://doi.org/10.1108/IMR-02-2020-0017

Jazz. (2019), "About Us ", available at: https://jazz.com.pk/why-jazz/about-us/ (accessed 10 December 2019).

Jensen, R. and Szulanski, G. (2004), "Stickiness and the adaptation of organizational practices in cross-border knowledge transfers", Journal of International Business Studies, Vol. 35 No. 6, pp. 508-23.

Khan, Z., Lew, Y.K. and Marinova, S. (2019), "Exploitative and exploratory innovations in emerging economies: The role of realized absorptive capacity and learning intent", International Business Review, Vol. 28 No. 3, pp. 499-512.

Khatri, N., Baveja, A., Agrawal, N.M. and Brown, G.D. (2010), "HR and IT capabilities and complementarities in knowledge-intensive services", The International Journal of Human Resource Management, Vol. 21 No. 15, pp. 2889-909.

Kong, E., Poon, T. and Dean, J. (2007), "China Mobile to buy Paktel in first foreign deal", The Wall Street Journal, Vol. 23 January.

Lagarde, C. (2016), The Role of Emerging Markets in a New Global Partnership for Growth by IMF Managing Director Christine Lagarde, IMF, February 4.

Lebedev, S., Peng, M.W., Xie, E. and Stevens, C.E. (2015), "Mergers and acquisitions in and out of emerging economies", Journal of World Business, Vol. 50 No. 4, pp. 651-62.

Lopez, V.W.B. and Esteves, J. (2013), "Acquiring external knowledge to avoid wheel reinvention", Journal of Knowledge Management, Vol. 17 No. 1, pp. 87-105.

Marquis, C. and Raynard, M. (2015), "Institutional Strategies in Emerging Markets", The Academy of Management Annals, Vol. 9 No. 1, pp. 291-335.

Martin, X. and Salomon, R. (2003), "Knowledge transfer capacity and its implications for the theory of the multinational corporation", Journal of International Business Studies, Vol. 34 No. 4, pp. 356-73.

Martín-de Castro, G. (2015), "Knowledge management and innovation in knowledge-based and high-tech industrial markets: The role of openness and absorptive capacity", Industrial Marketing Management, Vol. 47, pp. 143-46.

McDermott, G.A. and Corredoira, R.A. (2010), "Network composition, collaborative ties, and upgrading in emerging-market firms: Lessons from the Argentine autoparts sector", Journal of International Business Studies, Vol. 41 No. 2, pp. 308-29.

Mol, M.J. and Brandl, K. (2018), "Bridging what we know: The effect of cognitive distance on knowledge-intensive business services produced offshore", International Business Review, Vol. 27 No. 3, pp. 669-77.

Nonaka, I. and Takeuchi, H. (1995), The knowledge creating company: How Japanese companies create the dynamics of innovation, Oxford University Press, New York. 
Park, C., Vertinsky, I. and Becerra, M. (2015), "Transfer of tacit vs. explicit knowledge and performance in international joint ventures: The role of age", International Business Review, Vol. 24 No. 1, pp. 89-101.

Paulin, D. and Suneson, K. (2012), "Knowledge transfer, knowledge sharing and knowledge barriers-three blurry terms in KM", The Electronic Journal of Knowledge Management, Vol. 10 No. 1, pp. 81-91.

Pérez-Nordtvedt, L., Kedia, B.L., Datta, D.K. and Rasheed, A.A. (2008), "Effectiveness and efficiency of cross-border knowledge transfer: an empirical examination", Journal of Management Studies, Vol. 45 No. 4, pp. 699-729.

PTA. (2019), Annual Report, Pakistan Telecommunication Authority, Islamabad, Pakistan.

Rammal, H.G. (2019), "Innovation and International Entrepreneurship: Will the Digital Platform Serve All?", International Journal of Economics, Business, and Entrepreneurship, Vol. 2 No. 2, pp. 97-103.

Rammal, H.G. and Rose, E.L. (2014), "New Perspectives on the Internationalization of Service Firms", International Marketing Review, Vol. 31 No. 6, pp. 550-56.

Shearmur, R., Doloreux, D. and Laperrière, A. (2015), "Is the degree of internationalization associated with the use of knowledge intensive services or with innovation", International Business Review, Vol. 24 No. 3, pp. 457-65.

Simonin, B.L. (2004), "An Empirical Investigation of the Process of Knowledge Transfer in International Strategic Alliances", Journal of International Business Studies, Vol. 35 No. 5, pp. 407-27.

Søberg, P.V. and Wæhrens, B.V. (2019), "Subsidiary autonomy and knowledge transfer", Journal of Global Operations and Strategic Sourcing, Vol. 13 No. 2, pp. 149-69.

Song, J. (2014), "Subsidiary absorptive capacity and knowledge transfer within multinational corporations", Journal of International Business Studies, Vol. 45 No. 1, pp. 73-84.

Spraggon, M. and Bodolica, V. (2012), "A multidimensional taxonomy of intra-firm knowledge transfer processes", Journal of Business Research, Vol. 65 No. 9, pp. 1273-82.

Statista. (2019), "Countries with the highest number of mobile-cellular telephone subscriptions in 2018", available at: https://www.statista.com/statistics/268232/top-10-countries-bynumber-of-mobile-cellular-subscriptions/ (accessed 5 December 2019).

Szulanski, G. (1995), "Unpacking Stickiness: An Empirical Investigation of the Barriers to Transfer Best Practice Inside the Firm", in Academy of Management Proceedings, Academy of Management Briarcliff Manor, NY 10510, pp. 437-41.

Szulanski, G., Ringov, D. and Jensen, R.J. (2016), "Overcoming Stickiness: How the Timing of Knowledge Transfer Methods Affects Transfer Difficulty", Organization Science, Vol. 27 No. 2, pp. 304-22.

Telenor. (2019), "Company Information", available at: https://www.telenor.com.pk/ (accessed 17 November 2019).

The World Bank. (2020), "Enterprise Surveys", available at: www.enterprisesurveys.org (accessed 3 March 2020).

Tortoriello, M., Reagans, R. and McEvily, B. (2012), "Bridging the knowledge gap: The influence of strong ties, network cohesion, and network range on the transfer of knowledge between organizational units", Organization Science, Vol. 23 No. 4, pp. 1024-39.

Ufone. (2019), "About Us", available at: https://www.ufone.com/ (accessed 10 November 2019).

United Nations Development Programme. (2021), "Human Development Reports: Pakistan", available at: http://hdr.undp.org/en/countries/profiles/PAK (accessed 15 March 2021).

US Census. (2019), "Current Population", available at: https://www.census.gov/popclock/print.php?component=counter (accessed 21 November 2019). 
van der Heiden, P., Pohl, C., Bin Mansor, S. and van Genderen, J. (2015), "The role of education and training in absorptive capacity of international technology transfer in the aerospace sector", Progress in Aerospace Sciences, Vol. 76, pp. 42-54.

Wang, Z. and Wang, N. (2012), "Knowledge sharing, innovation and firm performance", Expert systems with applications, Vol. 39 No. 10, pp. 8899-908.

Williams, C. and Lee, S.H. (2011), "Entrepreneurial contexts and knowledge coordination within the multinational corporation", Journal of World Business, Vol. 46 No. 2, pp. 253-64.

Yuliansyah, Y., Rammal, H.G. and Rose, E.L. (2016), "Business Strategy \& Performance in Indonesia's Service Sector", Journal of Asia Business Studies, Vol. 10 No. 2, pp. 164 - 82.

Zahra, S.A., Ireland, R.D. and Hitt, M.A. (2000), "International expansion by new venture firms: International diversity, mode of market entry, technological learning, and performance", Academy of Management Journal, Vol. 43 No. 5, pp. 925-50.

Zaman, Q. (2019), Double taxation and frequent shutdowns limit digital participation in Pakistan, DW.com (9 April), https://p.dw.com/p/3EtCJ

Zeschky, M., Widenmayer, B. and Gassmann, O. (2011), "Frugal Innovation in Emerging Markets", Research-Technology Management, Vol. 54 No. 4, pp. 38-45.

Zhang, Y., Li, H., Li, Y. and Zhou, L.-A. (2010), "FDI spillovers in an emerging market: the role of foreign firms' country origin diversity and domestic firms' absorptive capacity", Strategic Management Journal, Vol. 31 No. 9, pp. 969-89.

Zong. (2019), "Company profile", available at: https://www.zong.com.pk/ (accessed 20 November 2019). 